\title{
The Destruction of Cultural Property in the Syrian Conflict: Legal Implications and Obligations
}

\section{Emma Cunliffe*}

\author{
Nibal Muhesen ${ }^{\dagger}$
}

\section{Marina Lostal ${ }^{\ddagger}$}

\begin{abstract}
This article comes as the conflict in Syria has entered its fifth year, bringing with it loss of life and the displacement of the Syrian people as well as extensive damage to, and destruction of, the country's cultural heritage. This article will first provide an overview and explanation of the national and international legal framework for protecting cultural property in conflict as it applies to the Syrian State and the non-State actors involved, using examples from the whole conflict, including the recent actions of Da'esh. Second, we demonstrate that the destruction of all types of cultural property, regardless of its importance, can be considered a prosecutable violation of these laws, and we examine the possibilities for prosecution. Following from this discussion, we question whether the existing framework can be considered effective and consider the role the international heritage community can play.
\end{abstract}

\footnotetext{
*Endangered Archaeology in the Middle East and North Africa, Institute of Archaeology, University of Oxford, United Kingdom; Email: emma.cunliffe@arch.ox.ac.uk

${ }^{\dagger}$ Archaeology and Heritage of Syria, Department of Cross-Cultural and Regional Studies, Carsten Niebuhr Center for Multi-Cultural Heritage, University of Copenhagen, Denmark

${ }^{\ddagger}$ Lecturer in International Law, Hague University, The Netherlands

ACKNOWLEDGMENTS: We are grateful to the University of Copenhagen and to Ingolf Thuesen, the head of the Department of Cross-Cultural and Regional Studies, for his continuous support for the work on Syrian archaeology and heritage. We are also grateful to Jack Williams, Georgia State University College of Law, for his comments on an early version of this article, and to Roger O'Keefe, for his comments on military necessity.
} 
The destruction and protection of cultural heritage in armed conflicts has been a feature of war for thousands of years and has received increasing international focus over the last two decades. While cultural heritage is threatened during peacetime, the severest damage takes place during social disorder and conflict, not only resulting in the loss of something unique and irreplaceable but also psychologically affecting the communities linked to it ${ }^{1}$ and potentially causing increased violence. ${ }^{2}$ Furthermore, it is linked to cultural cleansing - the removal of communities by eliminating their presence in the landscape, leaving them with no "home" to return to, should such an event become possible. ${ }^{3}$ Cultural protection, on the other hand, is increasingly linked to the recovery of psychological trauma and peace building during and after conflict, in addition to the economic tourism benefits it can provide. $^{4}$

In contrast, it is sometimes argued that the targeting of sites and monuments is irrelevant, given the other extensive human rights abuses that often accompany it. However, international humanitarian law (IHL), which is the body of international law that regulates the conduct of armed conflict and seeks to limit its effects, protecting people who are not part of the hostilities, binds those involved in a conflict to respect cultural property and promote its protection. The violation of this core obligation constitutes a war crime, and, under certain circumstances, its destruction may even amount to crimes against humanity, as explained by the International Criminal Tribunal for the former Yugoslavia:

When perpetrated with the requisite discriminatory intent, [destruction] amounts to an attack on the very religious identity of the people. As such it manifests a nearly pure expression of the notion of "crimes against humanity" for all of humanity is indeed injured by the destruction. ${ }^{5}$

The conflict in Syria has led to hundreds of thousands of deaths, millions of displaced people, and the damage and destruction of the country's cultural heritage. Although the generally accepted start date is 15 March 2011, "armed conflict" - the point at which a conflict moves beyond an internal disturbance and IHL becomes applicable—was not officially declared until June $2012 .{ }^{6}$ The cultural heritage in Syria has been profoundly involved in the conflict since the beginning, when the eighth-century al-Omari mosque was shelled. ${ }^{7}$ Reports of damage to historic mosques, churches, and archaeological and heritage sites have continued to mount, and by 27 June 2011, the first group, Le Patrimoine archéologique syrien en danger, had formed to record and raise awareness of the extent of the damage. Today, Syria's heritage is still continuously exposed to various actions that are resulting in partial or total destruction.

There is a national and international legal framework designed for cultural property protection (CPP) in such situations, but (as will be shown) too often it is not applied or enforced, and it is little understood by most cultural heritage professionals. The Syrian conflict is particularly complex as it is asymmetrical (that is, internal and involving the State and non-State actors ${ }^{8}$ ) rather than between State parties. ${ }^{9}$ 
This article will first provide an overview and explanation of the legal framework for protecting cultural property in conflict as it applies in Syria. Previous studies have focused on World Heritage sites ${ }^{10}$ or on specific applications of law. ${ }^{11}$ Second, we will demonstrate that the destruction of all types of cultural property, regardless of its importance, can be considered a prosecutable violation of law. Following from this discussion, we will question whether the existing framework can be considered effective and consider the role the international heritage community can play.

\section{THE NATURE OF THE DAMAGE}

Syria contains some of the most globally varied and important cultural heritage in the Mediterranean: religion and tangible and intangible heritage have intertwined over many millennia. The country hosts six World Heritage sites, which are all now on the List of World Heritage in Danger, and 11 sites on the World Heritage Tentative List. ${ }^{12}$ However, while it has been argued that Syria's world heritage is deserving of special legal protection, ${ }^{13}$ and international investigation has often focused on these conspicuous sites, ${ }^{14}$ Syria also has a rich national and local heritage, reflecting the diversity of its population. While many Syrians whom the authors have spoken to feel a keen sense of pride in their "universal heritage," it is often national or local heritage that contributes most to a sense of identity, ${ }^{15}$ and both have also been devastated. ${ }^{16}$ Their loss should not be overshadowed by the destruction of the higher profile World Heritage sites, so this article will focus as far as possible on other examples.

The direct targeting and destruction of sites can have multiple causes: the prevention of the location's political use; accidental collateral damage in armed clashes; part of indiscriminate firing of guns and mortars at entire areas; or an obstacle to other targets and purposively targeted to clear a path. ${ }^{17}$ In addition, many sites are reused, whether because they are conveniently located, provide a convenient existing structure for reuse, or are valuable for their historic and still current strategic vantage points. There are also occasions when sites are deliberately targeted for their associations with specific cultural groups.

Looting, and the ensuing illicit trade, is also a common source of extensive damage. Even the removal of objects with shovels can cause extensive damage to the fabric of a site, and many sites have been bulldozed to enable easier access to saleable objects. These objects are as much a part of Syria's heritage as the sites and museums they come from, and once stolen, are extremely difficult to trace and return, particularly since objects looted from sites are unrecorded.

While reoccupation and illegal building were problematic before the conflict, ${ }^{18}$ the deterioration of security has enabled an increase in these issues. The conflict has led to a massive displacement of people and the abandonment of entire villages. Desperate for shelter, groups of civilians have reoccupied ancient sites and even underground tombs and adapted them to their life. 
Lastly, it is important to emphasize the damage caused by iconoclasm, a specific form of damage that is increasing in the Syrian conflict. Although the seventeenthcentury term specifically means the "breaking of images,"19 in current literature, it is usually given a wider definition that includes the destruction of specific religious and symbolic buildings for a religiously motivated purpose, rather than for a militaristic or social one. ${ }^{20}$ There have been increasing documented outbreaks of violence against religious and ethnic objects and structures, committed by extremists. International attention, in particular, is now focused on the extremist group Da'esh (more commonly known as the Islamic State of Iraq and the Levant (ISIS)), who have destroyed monuments and sites as part of their campaign against idolatry-for example, in Raqqa, and at Heraqla. ${ }^{21}$ In addition, they have been linked to the extensive looting and sale of many more artifacts to purchase weapons, causing some to question the religious motivations underlying their actions. ${ }^{22}$

\title{
CULTURAL HERITAGE OR CULTURAL PROPERTY?
}

It is important to understand that, legally speaking, distinctions are frequently made between cultural property and the broader term cultural heritage, and both international and national definitions of heritage vary. This article focuses on physical heritage and so uses the legal definition for cultural property in the 1954 Convention for the Protection of Cultural Property in the Event of Armed Conflict (Hague Convention). ${ }^{23}$ Article 1 specifies that cultural property includes:

\begin{abstract}
(a) movable or immovable property of great importance ... such as monuments of architecture, art or history, whether religious or secular; archaeological sites; groups of buildings which, as a whole, are of historical or artistic interest; works of art; manuscripts, books and other objects of artistic, historical or archaeological interest; as well as scientific collections and important collections of books or archives or of reproductions of the property defined above; (b) buildings whose main and effective purpose is to preserve or exhibit the movable cultural property ... (c) centers containing a large amount of cultural property.
\end{abstract}

\section{TREATY AND CUSTOMARY LAW}

Changes in the conduct of war, both ethical and operative, have resulted in a complex legal cultural protection framework in national and international law. Building on their growing international acceptance, there is a gradually increasing body of precedent for prosecution and implementation. However, to the nonspecialist, the different legal terms and their implications remain confusing. There is an important distinction between customary international law and the more commonly known form of international law, called treaty law. International conventions ("treaties") are legal instruments negotiated, elaborated, and adopted by States. However, they rarely cover non-international (that is, internal) armed conflicts, are not always ratified by all States, and are therefore binding in principle 
only on State parties. Treaties only become binding on those States that decide to join. A signature expresses the intention of the State to comply with a treaty, but States must still ratify it or accede to it (usually involving national parliamentary approval) in order to be bound.

Therefore, not all international legislation of this type referring to CPP is binding on all parties involved in the Syria conflict. The country of Syria is only explicitly bound by the treaties it has ratified and less definitively by the treaties it has signed. How these treaties apply to non-State actors is complex and still being examined by legal experts. However, even if a State has not signed or ratified a convention, some treaties have become customary international law, which is binding on all States. According to the International Committee of the Red Cross (ICRC):

[It] is made up of rules that come from "a general practice accepted as law" and that exist independent of treaty law. Customary international humanitarian law is of crucial importance in today's armed conflicts because it fills gaps left by treaty law in both international and noninternational conflicts ... To prove that a certain rule is customary, one has to show that it is reflected in state practice and that the international community believes that such practice is required as a matter of law. ${ }^{24}$

Bearing this in mind, we will now present a brief overview of the key legal treaties and customary laws applicable in Syria, beginning with cultural heritage destruction in IHL, and then examine the more specific expressions of CPP in treaty law and then in domestic law. Through this overview, we will demonstrate the many ways the destruction of cultural property violates national and international law, even given the asymmetric nature of the conflict. However, it is not enough to have a legal framework, and the final section will examine the possibilities for enforcement.

\section{INTERNATIONAL CUSTOMARY LAW}

International human rights law (IHRL) includes the destruction of cultural heritage, and Syria has acceded to / ratified many international conventions that it is therefore obliged to comply. The 1948 Universal Declaration of Human Rights (ratified by Syria) forms the basis of IHRL. Article 27 states that "[e]veryone has the right to freely participate in the cultural life of the community, to enjoy the arts." 25 As a declaration (compared to, for example, a convention), it is not binding, but the 1976 International Covenant on Economic, Social and Cultural Rights (ICESCR) (ratified by Syria) guarantees some of its rights. ${ }^{26}$ According to the ICESCR Committee, it obligates the preservation and presentation of mankind's cultural heritage (Article 15(1)(a)). The UN Human Rights Council made it clear that it is applicable in conflict situations. ${ }^{27}$ It is debatable to what extent this applies to Syria's entire cultural heritage, but since world heritage is "heritage of mankind as a whole," the damage and partial destruction of all of its World Heritage sites must surely qualify as a violation. For example, military forces have occupied 
parts of Aleppo, including the citadel and the Umayyad Mosque. This has led to the targeting of both sites, resulting in structural damage and the loss of the historic Al-Wakfya library and the minaret of the mosque. One recent examination of 210 locations in the World Heritage site determined that 22 had been destroyed, 48 were severely damaged, 33 were moderately damaged, and a further 32 had sustained possible damage. ${ }^{28}$ Causes included shelling impacts (which damaged, for example, the citadel glacis and destroying the minaret of the Umayyad Mosque), fires caused by shelling (which destroyed, for example, most of the ancient souq and the historic Al-Wakfya library), and the use of explosives to target military occupied buildings (which were detonated, for example, in the tunnels under the historic Carlton Hotel, destroying it) (Figure 1).

The 1949 Geneva Convention and its three protocols (of which Syria is a party only to the first) are often cited in discussions of conflict legislation: they are considered a cornerstone of IHL and the subset of IHRL that applies to armed conflicts, setting baselines for the treatment of those uninvolved in the conflict. ${ }^{29}$ In the context of CPP, they ban the "pillage" (that is, looting) of civilian properties, including cultural property, and prohibit acts of hostility against, the military use of, or reprisals against historic monuments and works of art. However, it is with respect to these treaties that we see the first complexities of the asymmetric conflict. Syria is not party to Additional Protocol II, which extends the previous

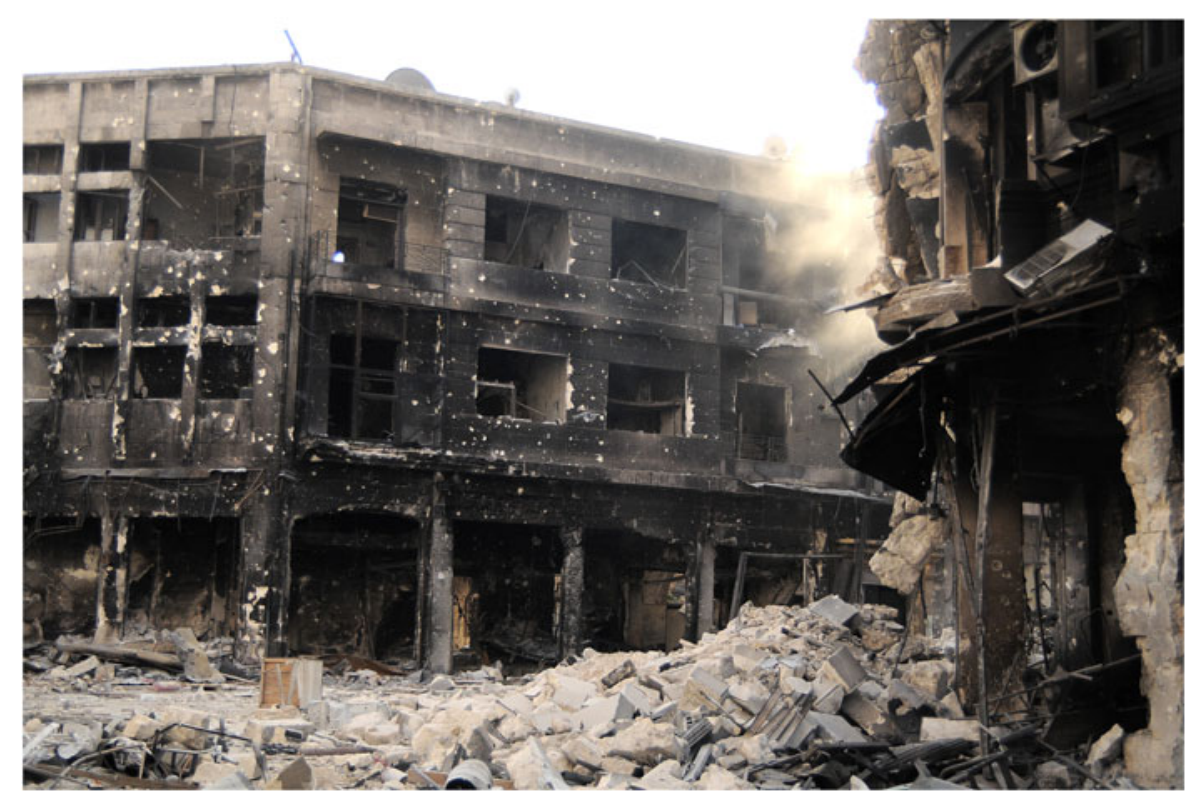

Figure 1. The destruction within the Ancient City of Aleppo, which hosts a very rich urban heritage, including mosques, shrines, and public places such as the souk and the khans. Some of the city's urban heritage has been severely affected, and some has almost vanished in the conflict. This photograph, showing rubble fills in the district of Sharia al-Sweiqa, was taken in early November 2012 ( ( ) AP Images / Polfoto / Monica Prieto). 
statues to internal conflicts, so this important legislation is not applicable. ${ }^{30}$ Pillaging is nevertheless forbidden by the 1907 Hague Convention IV and the Regulations Concerning the Laws and Customs of War on Land (Hague Regulations), which is considered to be an important part of the body of customary international law (Articles 28 and 47). ${ }^{31}$

\section{TREATY LAW}

Today, the principal instrument for CPP is the 1954 Convention for the Protection of Cultural Property in the Event of Armed Conflict (Hague Convention) (ratified by Syria) and its additional 1954 First Protocol (ratified by Syria) and 1999 Second Protocol (signed but not ratified by Syria). These treaties complement the Hague Regulations. Also of international relevance is the 1970 Convention on the Means of Prohibiting and Preventing the Illicit Import, Export and Transfer of Ownership of Cultural Property (UNESCO Convention) (ratified by Syria), while within Syria, the key legislation is the 1963 Antiquities Law. ${ }^{32}$ The 1995 Convention on Stolen or Illegally Exported Cultural Objects (UNIDROIT Convention), which would provide a more detailed protection framework, has not been signed by Syria. ${ }^{33}$ These tools are intended to help safeguard cultural property by preventing its destruction or use for military purposes and by providing systems of protection and rules for combatants or occupying forces when dealing with the transport and use of cultural property. ${ }^{34}$ While there are inconsistencies in their approaches, ${ }^{35}$ the destruction of culture or cultural property is a war crime.

Lastly, there are also a number of UN Educational, Scientific, and Cultural Organization (UNESCO) conventions that deal with the importance and management of heritage. For the most part, these conventions lack specific obligations, and it is not clear what level of protection is owed as a result of them; therefore they are accorded only a brief discussion.

The 1954 Hague Convention, the Hague Regulations, and the First and Second Protocols are the only legal instruments specifically concerned with the protection of cultural property in armed conflict, defining cultural property and outlining appropriate measures to undertake in peacetime and during conflict. All warring parties, including non-state actors, are bound to observe, as a minimum, the provisions relating to respect for cultural property (Article 19(1)). ${ }^{36}$ States also agree to prohibit and prevent pillage and vandalism directed against sites, to refrain from direct attack, seizure, or capture, and in cases of occupation, to support the local authority to protect sites. Using cultural property or its immediate surroundings for military purposes that may expose it to direct attack is prohibited except in cases of "imperative military necessity" (Article 4). Additional articles include the use of a "distinctive emblem" that may be placed on cultural property to protect it from any attacks and the possibility of granting some cultural property "special protection" (Articles 6 and 8). In addition, each State party agrees to prevent the exportation of cultural property if it occupies an area and to return cultural 
property to the competent authorities (Article 1 of the First Protocol). Neither treaty includes direct rules for enforcement, leaving this issue to the State parties.

Under the Second Protocol, rather than simply "ensuring respect," parties must "do everything feasible" to verify objectives are not cultural property, take all feasible precautions to minimize damage, and refrain from attacks that would cause incidental damage (Article 7a). The Second Protocol also contains clarification of "imperative military necessity" and rules for enforcement (Articles 6 and 15-21). There is also a revised system of "special protection," called "enhanced protection" (Article 10), since the initial system was unfeasible. Most importantly, it applies all of its provisions to internal conflicts. Although Syria has not ratified the Second Protocol, it did sign it at the time of its adoption. According to the principles of the 1969 Vienna Convention on the Law of Treaties, State parties to these conventions have made a formal agreement to comply with the tenets. ${ }^{37}$ A State that has signed, but not ratified, a treaty has stated its intent to ratify the treaty and is therefore obliged to refrain from "acts which would defeat the object and purpose" of the treaty. These obligations end if the State declares that it does not intend to become a party to the treaty (Article 18). Syria has made no such declaration.

A recent study carried out by the ICRC suggests that the basic principles of the 1954 Hague Convention have become part of customary law and are applicable in internal conflicts. ${ }^{38}$ The study was based on an examination and review of State practice and "belief that such practice is required, prohibited or allowed ... as a matter of law." 39 While there is no global agreement regarding which parts of the Hague Convention reflect customary law, the core provisions applicable to both State and non-State parties include: the responsibility of nations to protect cultural property in their own territory; the obligation to avoid targeting cultural sites (subject to the imperative military necessity waiver); the obligation to refrain from acts of reprisal against cultural property; and the obligation to prevent (members of the military from engaging in) theft, pillage, and the misappropriation of cultural property. ${ }^{40}$

Given the core provisions in the Hague Convention that are applicable in noninternational conflicts such as Syria, the potential list of violations is considerable. While there is no agreement about what constitutes "respect," a number of sites appear to have been targeted for no obvious military reasons. In some cases, the damage has been so extensive that not only significant buildings but also large sections of entire cities have been reduced to rubble, as took place, as previously discussed, in Aleppo as well as in large areas of historic (and modern) Homs (Figure 2). Many more sites were damaged when these buildings (and the surroundings) were used for military purposes and then damaged even more when they were subsequently targeted. A considerable number of videos and images show the military (re)use of strategic locations such as citadels (for example, Homs or Qal'at al-Shmemis), high mosque minarets as sniper positions (such as the Abu Bakr Mosque in Daraa), and even the use of churches, museums, and historic houses as army barracks, training camps, and field hospitals (for example, the Museum of 


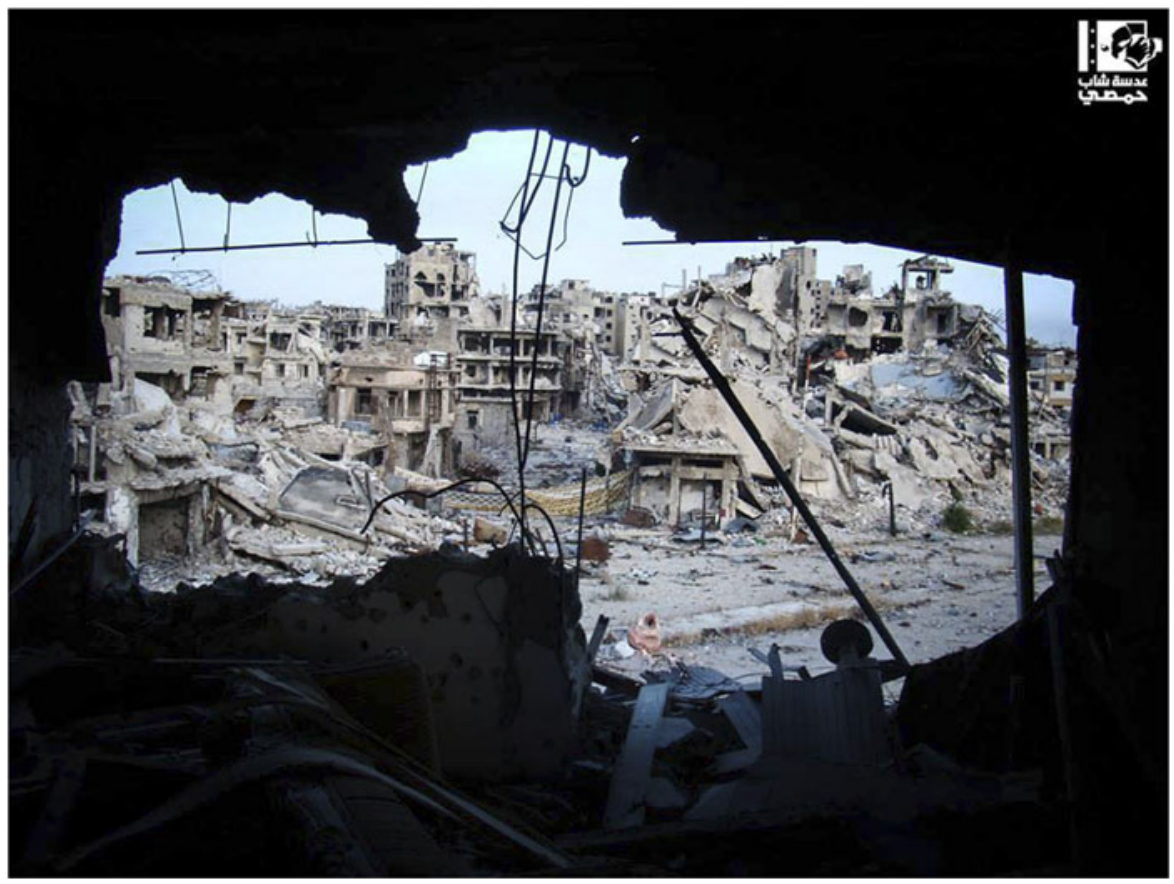

FIgURE 2. The destruction within the city of Homs, showing clear evidence of the lawless, systematic destruction of the urban landscape from heavy fighting. This photograph, which shows damaged buildings in the Jouret al-Chiyah neighborhood, was taken in early June 2013 by a citizen journalist and provided by "Lens Young Homsi" (ㅇ Polfoto / AP Images).

Ma'arat al-Nu'man, Idlib, or Deir Cherubim, Saydnaya). Aside from the damage caused by carelessness, military occupation often involves the digging and construction of defensive positions and tank emplacements in the archaeological layers, such as at Ebla, ${ }^{41}$ Apamea, and Tell Jifar. ${ }^{42}$ These actions fall under the prohibition of acts of hostility directed against cultural property and the use of it and its surroundings for purposes that may lead to their damage or destruction (both of which may be waived for imperative military necessity).

Since military use is one of the greatest causes of damage to sites, the imperative military necessity' waiver deserves a brief consideration. This exception is not defined in the 1954 Hague Convention itself. It was clarified in the Second Protocol to which Syria is not a party. It has been argued that the provision significantly undermines the provisions as a whole, ${ }^{43}$ and the entire concept has been extensively debated, ${ }^{44}$ but no consensus has been reached. Marina Lostal has argued that the 1954 Hague Convention provides a stringent legal standard with respect to the prohibition of actions of hostility against cultural property, as a site must constitute a "military objective" before the imperative military necessity waiver can be considered. ${ }^{45}$ Given this, the many attacks upon civilian cultural property, and the first occupation of a site for military purposes, must be considered unlawful. 
If a site is used for military purposes, under some circumstances it may then be lawful to attack the site. Of the various examples discussed earlier, conflict occurred at Homs citadel and Ebla (which both changed hands several times), Apamea, the Museum of Ma'arat al-Nu'man, and the Abu Bakr mosque only after the site was subject to military use.

The determination of military necessity is an "open-textured" international standard - that is to say, it has an unspecific definition-and investigations would be conducted by the State applying the standard ${ }^{46}$ and interpreted by reference to the concept of the "military objective." ${ }^{77}$ Any international court or tribunal with jurisdiction over the matter can review it. ${ }^{48}$ However, as modern technological capabilities advance, it is likely that the type of attack must also be considered, in addition to determining the necessity of the attack, to determine if excessive force resulting in destruction was used. ${ }^{49}$ General Dwight Eisenhower wrote in his staff orders of 29 December 1943: “The phrase 'military necessity' is sometimes used where it would be more truthful to speak of military convenience or even of personal convenience. I do not want it to cloak slackness or indifference." Detailed investigations are necessary on a case-by-case basis when the security situation allows. Aspects to consider should include military records and diaries and witness and expert testimonies, along with other information that may help to provide insight into the military situation at the time of the incident. It is important to stress that the imperative military necessity test must not be made with hindsight but that it must take into account the circumstances of the time.

Article 6 of the Hague Convention suggests marking sites with a distinctive emblem, but this is problematic. Directly identifying a place as important can associate it with a particular culture and can render it a deliberate target (as happened in Croatia), leading to disagreement about whether to implement the provision since compliance could also result in destruction. ${ }^{50}$ Fortunately, it is not mandatory, so there is no penalty for failure to comply.

The last aspect of the 1954 Hague Convention that requires elaboration is the prohibition and prevention of pillage (Article 4(3)). Illegal excavations and thefts have been extensively reported at sites (and, to a much lesser extent, at museums) across Syria. ${ }^{51}$ Although looting is destructive, it has led in some cases to the site's near-total destruction, such as at Dura Europos..$^{52}$ Official sources list several museums that have been looted, but social media groups suggest the true number could be higher. ${ }^{53}$ The majority of the items taken have been lost without a trace, even with international assistance. An eighth-century Aramaic golden statue was stolen from the museum of Hama at the start of the conflict: the theft was reported to Interpol and its image was circulated on the December 2012 list of most wanted missing objects, but the item was never located (Figure 3).

According to the 1954 Hague Convention, States agree to prohibit and prevent the pillaging of sites. However, it has been argued that while the literal interpretation of this phrase seems to impose an obligation to prevent any pillage, including such action by the local population, it may actually only refer to acts committed by 


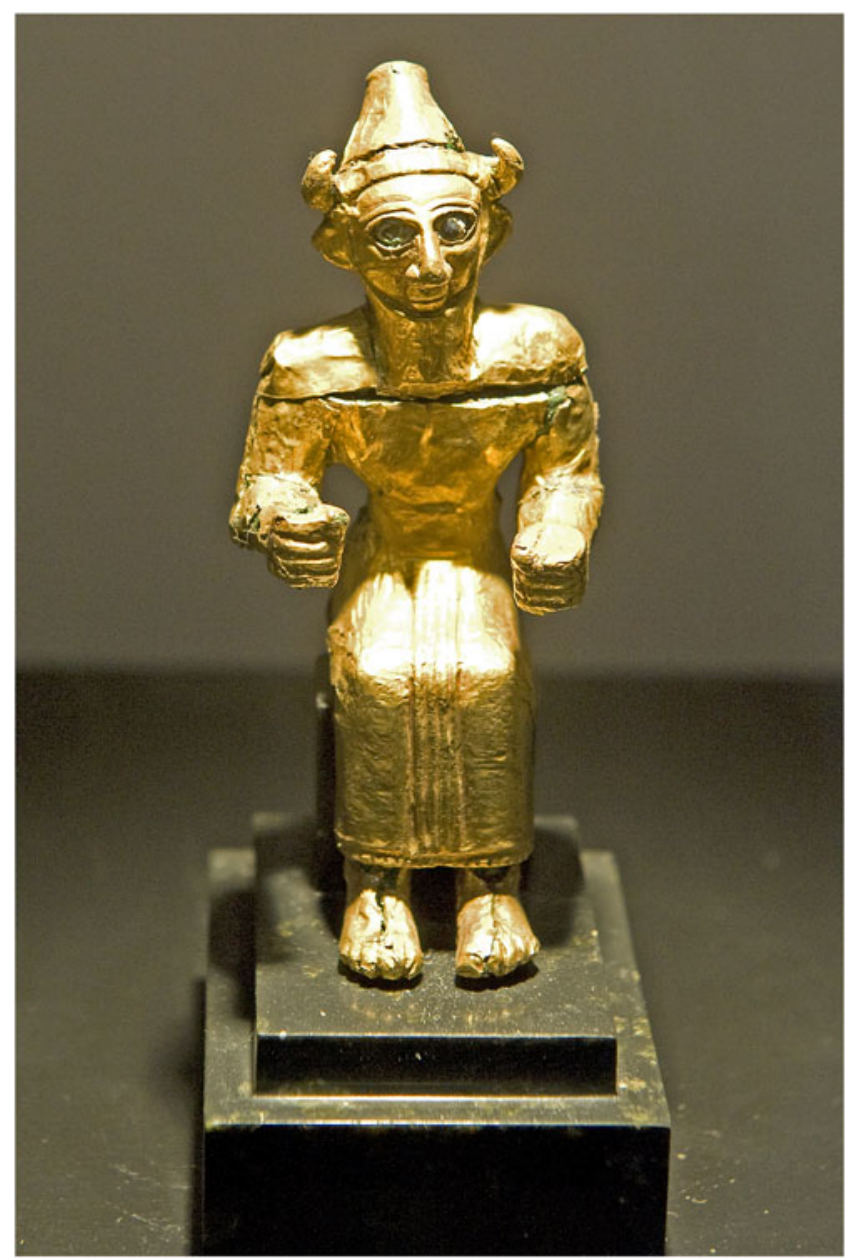

Figure 3. An Aramaic gilt bronze statue dating to the eighth-century вС was stolen from the museum of Hama in the early stages of the conflict. In December 2012, the statue was put on Interpol's “The Most Wanted Works of Art” poster, and in May 2012, Interpol also called for vigilance about the looting of ancient mosaics in Syria (photograph from 2009, courtesy of D. Osseman).

the military of the State party. ${ }^{54}$ While military parties may have been complicit in the looting at some sites-for example, in Apamea-the looting has been far more widespread than what is reported, and this phrase is very limiting. ${ }^{55}$ However, under IHL, "each party to the conflict must protect cultural property (applicable in international and non-international armed conflict)." 56 This protection should include the prevention of looting as it can cause catastrophic site destruction, but this has not yet been explored within the legal framework and, instead, legal cases have only focused on the removal of objects. ${ }^{57}$

The 1970 UNESCO Convention is the most broadly ratified treaty regarding illicit cultural property. ${ }^{58}$ It clearly states that "the export and transfer of ownership 
of cultural property under compulsion arising directly or indirectly from the occupation of a country by a foreign power shall be regarded as illicit." It defines preventative measures State parties should take to prevent the import and acquisition of illegally exported cultural property and binds them to return objects if requested by the State party of origin. This latter provision covers only stolen inventoried objects, and, unfortunately, illicitly excavated objects are excluded. The date of the convention-1970 - is usually taken as the date from which these provisions should be enforced. Objects that were illegally removed before this date are not covered.

Whilst Syria has ratified (but not implemented) the UNESCO Convention, it only deals with looting while States are occupied by a foreign power. All States must participate in the fight against illicit trafficking, through increased vigilance against smuggling and by helping to restore stolen objects. The main difficulty is confirming that objects were looted from Syria. Not only is it extremely difficult to trace previously unknown objects taken directly from sites, but also not all museum collections have been inventoried. This latter point is a key requirement of the convention, and the Syrian Directorate General of Antiquities and Museums (DGAM) are working to rectify this situation. In addition, recovery requires international co-operation, which is dependent upon the recognition of State parties by State parties. The United States, for example, does not currently recognize the Syrian government as a legitimate authority and has no diplomatic relations with them. Under these conditions, restitution may not be legally possible. After several years of pressure, the UN Security Council adopted Resolution 2199 in February 2015, condemning the destruction of Syria's heritage and reaffirming the importance of preventing the illicit traffic of Syrian artifacts, as it did in Iraq in 2003. Experience from Iraq in 2003 suggested that a similar prohibition reduced the amount of illicit material available on the international market. ${ }^{59}$ This has since been followed up by the adoption of the Operational Guidelines for the Implementation of the UNESCO Convention at the third Meeting of State Parties in May 2015 as well as a UNESCO-sponsored workshop that is seeking ways to counter the illicit traffic of cultural objects. ${ }^{60}$ However, the full implementation of both the UNESCO Convention and Resolution 2199 requires diplomatic relations to be implemented in all countries. While neighboring countries are working to repatriate recovered objects (with varying effort), the total is likely to be only a tiny fragment of those removed.

Furthermore, to establish accountability for such violations, and to determine if the Hague Convention is applicable, those responsible must be caught. The identity of the looters is largely unknown. The lack of centralized power in some areas has encouraged the emergence of organized groups who carry out both planned, selective looting and un-planned, "mob"-style looting. ${ }^{61}$ Some are armed gangs incorporating several hundred people, many of whom may be foreigners. Other illegal excavations are conducted on a much smaller scale and are more likely to have been conducted by local people, with motivations including poverty, greed, 
and money to fund the conflict. The sale of artifacts to buy arms by combatants is particularly noteworthy ${ }^{62}$ and has led to additional prosecutions.

At this point, it is worth returning to iconoclasm. Reports detail the destruction of historic Jewish and Islamic shrines, tombs, and representations of Islamic poets and caliphs in Raqqa, Damascus, Aleppo, Dera'a, and Idlib, ${ }^{63}$ many of which hold (or held) the remains of significant figures. Numerous churches and mosques have also been attacked. ${ }^{64}$ Actions include burning, vandalism, shooting, and stabbing of religious icons and historic documents; the looting of objects and statues; major structural damage; the blowing up of shrines, mihrabs, altars, and religious statues; and the removal of bells that called the community to prayer (Figures 4 and 5). The scale is staggering-for example, almost 1,500 mosques have been targeted apparently for various reasons, including religious extremism. ${ }^{65}$

Iconoclasm is not a specific crime, but it represents the removal of people's ability to participate in the cultural life of the community, as covered under general IHL, and it causes cultural property damage as defined in the 1954 Hague Convention. Religious sites and objects are protected, therefore, from attacks and prohibited from military use like other importance cultural property.

Finally, there are also a number of international conventions that deal with the importance and management of various forms of heritage: the 1972 UNESCO Convention Concerning the Protection of the World Cultural and Natural Heritage (World Heritage Convention) (ratified by Syria); ${ }^{66}$ the 2003 UNESCO Convention

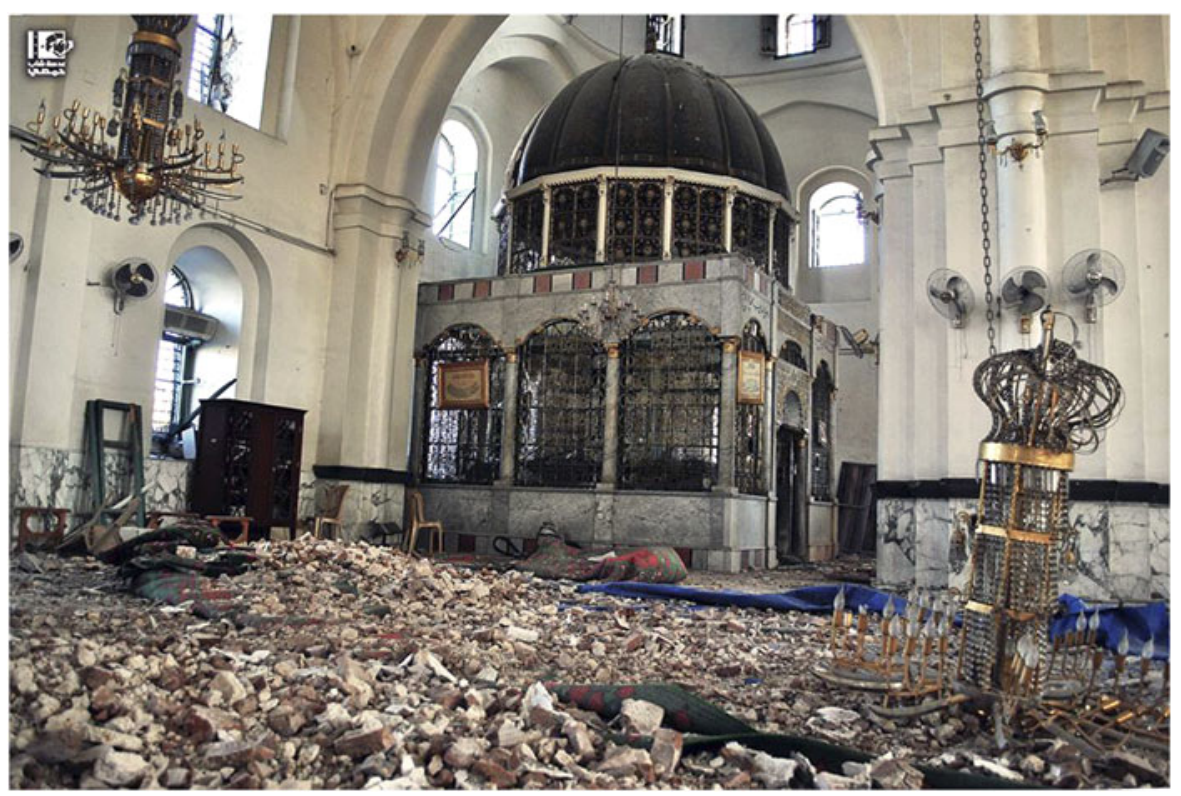

Figure 4. The destruction of the inside of the Khalid Ibn Al-Walid mosque in Homs. It is believed to contain the tomb of the Muslim military leader Khalid Ibn Al-Walid. The inside of the mosque has been severely affected, and its roof has collapsed. In addition, the mihrab (niche) was also damaged ( Polfoto / AP Images). 


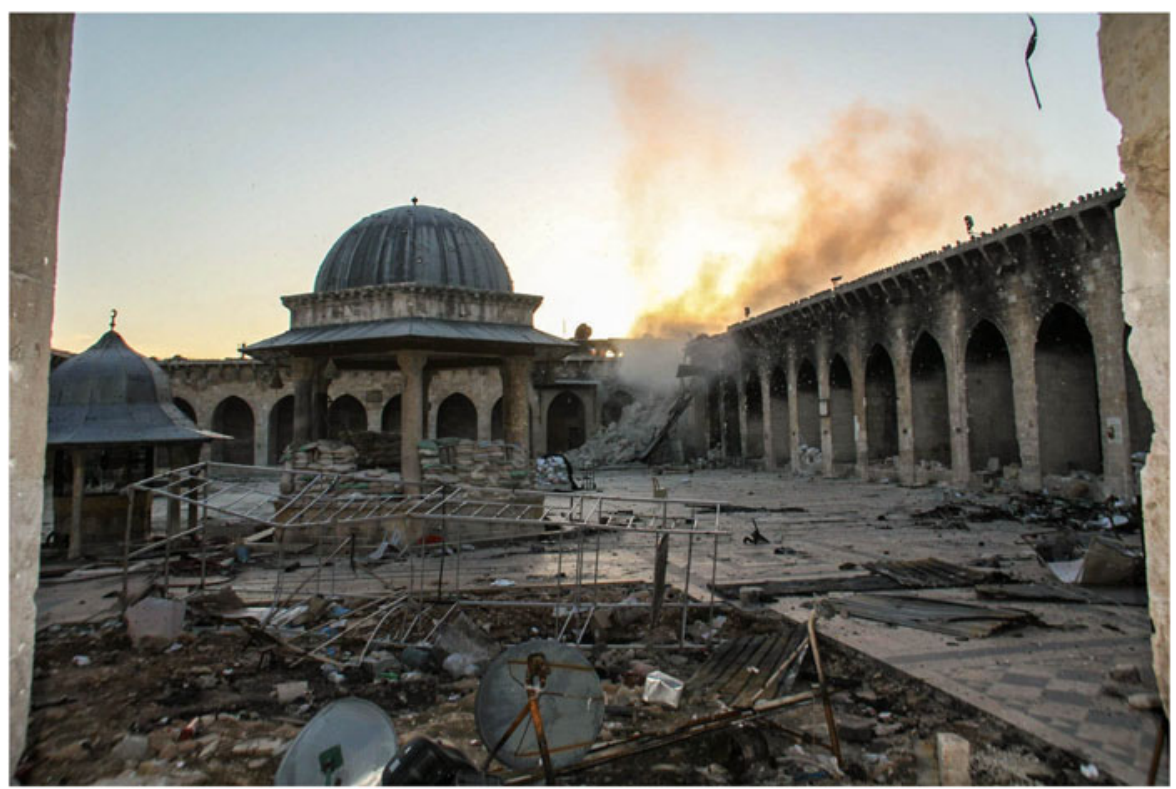

Figure 5. The destruction at the eighth-century AD Umayyad Mosque in Aleppo, which caught fire in August 2012. Besides the severe damage to the prayer hall and the mihrab (niche), precious Islamic and Pre-Islamic manuscripts were lost due to the conflagration that occurred in the library attached to the mosque in March 2013. The rubble at the corner of the photo indicates the place where the minaret stood (ㄷ Corbis Image).

for the Safeguarding of Intangible Cultural Heritage (ratified by Syria );67 and the 2005 UNESCO Convention on the Protection and the Promotion of the Diversity of Cultural Expressions (ratified by Syria). ${ }^{68}$ Although they represent binding conventions, their content is mostly programmatic and provide best practice guidelines. The World Heritage Convention operates as an exception, functioning at an international level, and requiring State Parties to submit reports detailing the management of sites. Sites that are considered threatened can be placed on the List of World Heritage in Danger, as Syria's have been, and potentially delisted. ${ }^{69}$

There are also a number of declarations, of which the most relevant is the UNESCO Declaration Concerning the Intentional Destruction of Cultural Heritage. ${ }^{70}$ It includes a call to members to do everything they can to prevent acts of intentional destruction of cultural heritage and requests its members to become parties to both of the Hague Convention protocols. Declarations such as this one represent the opinion of the majority of the Member States of UNESCO, but they are not legally binding. However, they can prompt the adoption of another international treaty or domestic legislation and may also be relevant in proving the opinion juris of customary international law (that is, put very simply, any actions carried out by a State are considered to be practically a legal obligation anyway). In the case of Syria, such declarations have been largely ineffective with regard to the adoption of the 1954 Hague Convention-one permanent member state of the 
UN Security Council still has yet to ratify it — the United Kingdom-and only time will tell if it helps reduce looting.

It should be noted that many of these conventions and treaties were not written with long-term occupation by states or other parties in mind, as has happened in Syria, and so they have no provisions to deal with these situations. In fact, IHL is only now beginning to examine the legal ramifications of such actions, and new developments/precedent rulings will have to be made.

\section{NATIONAL LEGAL PROVISIONS}

Cultural property in Syria is governed by the 1963 Antiquities Law, which was amended in 1999, pre-dating several of the key international treaties and conventions (although updates have been drafted. ${ }^{71}$ The Antiquities Law (Arabic qānūn al-Atār) explains the nature of Syrian heritage, regulating it with penalties in case of destruction or the failure to protect it: "It is prohibited to destroy, transform, and damage movable and immovable antiquities by writing on them, engraving them, or changing their features, or removing parts of them" (Chapter 1, Article 7). The Antiquities Law sets out laws against the forging and illicit traffic of Syrian cultural heritage, attributing the ownership of all antiquities and artifacts to the State. Penalties for offences against the country's heritage range from substantial fines to imprisonment for either short or long periods. Given this, all of the offences discussed above are crimes under the Antiquities Law, and some are more clearly elaborated. The Hague Convention, for example, prohibits military use of the undefined "immediate surroundings" of a site, while Chapter 2, Article 26, of the Antiquities Law states: "Heavy and hazardous industries, military facilities might not be built within 500 meters of registered immovable archaeological and historical properties." However, the specification that facilities might not be "built" could be interpreted to allow the creation or placement of movable or temporary facilities, such as existing mobile weapons arrays or military storage. Similarly, unlike the Hague Convention, the Antiquities Law explicitly recognizes the crime of looting, and forgery is also prohibited. All objects belong to the State, and, therefore, forgeries, object removal (whether from a site or a museum), and the attendant site destruction are all crimes. While forgeries might not seem problematic, in some cases, almost a third of objects seized were fake, tying up the resources of the bodies tackling the looting and encouraging market demand. ${ }^{72}$

In addition, the conflict has led to the massive displacement of people and the abandonment of entire villages. Desperate for shelter, groups of civilians have reoccupied ancient sites and even underground tombs and adapted them to their life. This has resulted in new buildings that violate the integrity of the site, the removal of archaeological material for new buildings, rubbish dumps, looting, and the targeting of the sites. This is particularly prevalent across the limestone massif in Idlib and the Aleppo provinces, home to the "Dead Cities," some of which form a World Heritage site, and at Bosra, where "the residents found the right moment 
to push through illegal projects (construction in protected area), [and] it is difficult to assess today the extent of their illegal actions." 73 The damage caused by the re-occupation of such sites by civilians is not covered under international law, which relates to military forces, so those responsible are only accountable under State law. However, the changes made to the sites do fall under the regulation of Chapter 1, Article 7, of the Antiquities Law with respect to destroying or transforming sites, and, as such, are crimes. Although, given the likely lack of viable alternatives for accommodation and shelter, it is questionable whether prosecution would be appropriate.

\section{THE LEGAL FRAMEWORK: REMARKS}

Cultural property clearly benefits from a system of legal protection that imposes the obligation to protect cultural property in times of armed conflict. However, the frameworks described are difficult to apply, and in the Syrian case, they have proven to be inadequate-various violations and offences to cultural and religious institutions and objects have taken place. The framework contains problems and a lack of clarity, relating to military necessity in particular. Furthermore, the treaties that broaden the scope of the obligations to cover internal conflicts have not been ratified, such as Additional Protocol II to the Geneva Conventions, the Second Protocol to the Hague Convention, or the UNIDROIT Convention. Even when ratified, these international conventions have not necessarily been incorporated into domestic legislation, so they have no supporting state infrastructure. Nonetheless, given its age, the Syrian Antiquities Law is holding up relatively well, with some sections being clearer than the international legislation. The revisions to the Antiquities Law are eagerly awaited, as they are expected to incorporate more inclusive definitions of heritage as well as the obligations from conventions that have been drafted since 1963. It has been demonstrated that the Antiquities Law is complemented by the Hague Convention, and, in some ways, they shore up some of the weaknesses of each other. It is hoped that the revisions will seek the best of both. However, it is unclear how the new statutes will be implemented, given the difficulties in enforcing the current Antiquities Law in the deteriorating security situation. The fact that the destruction can be classed as violations (and, as will be shown, as war crimes) demonstrates that there is a legal set of obligations that do protect cultural property in conflict. These laws have proven to be effective elsewhere (for example, during the North Atlantic Treaty Organization's operations in Libya). ${ }^{74}$ Therefore, the problem is not with the legal framework but, rather, with its enforcement.

\section{PROSECUTIONS AND INTERNATIONAL CRIMINAL LAW}

National and international legal frameworks promote and enforce the standards and values of the societies that created them, attempting to promote these standards 
and prevent the consequences of their avoidance by means of punishment. As such, they represent the aspirations of those societies and should be enforced. However, the nature of the conflict in Syria presents a particular challenge for the enforcement of law. The conflict involves multiple actors, some of whom are part of groups with chains of responsibility, and others are individuals (or may as well be). Ideas of "territory" and, therefore, responsibility are constantly shifting. In addition, the conflict is ongoing, and priorities and resources are unsurprisingly focused on ending the conflict. ${ }^{75}$

\section{National Prosecutions}

Nonetheless, in the first instance, violations involving cultural property can be tried in Syrian law courts as offences against the Antiquities Law, Article 28 of the Hague Convention, and IHL:

Syria is obliged to investigate, prosecute and punish the authors of
any such violations, irrespective of their allegiance ... The poten-
tial approaches to accountability ... would have to be supplemented by
national prosecutions in Syria at some point. Experience shows that only
a very limited number of cases can be dealt with by other States or the
international community. ${ }^{76}$

However, internal prosecutions are likely to wait until the conflict is resolved and are ultimately likely to favor the victors in the conflict.

\section{International Prosecutions}

Therefore, should the international community feel it is necessary, parties can be held responsible for violations of IHL. Based on the precedents of the ad hoc International Criminal Tribunal for the former Yugoslavia (ICTY), a permanent, treaty-based criminal court was created under the 1998 Rome Statute of the International Criminal Court (Rome Statute). ${ }^{77}$ The International Criminal Court (ICC) is intended as a last resort, investigating and prosecuting only where national courts have failed, and it is entirely independent.

The destruction of cultural property falls under Article 8 (which covers internal conflicts), which mandates that intentionally directing attacks against civilian objects or historic monuments that are not military objectives is classed as "war crimes." However, Article 8 has been described as "anachronistic, incomplete and inconsistent" since it fails to distinguish between the types or scales of attacks on cultural property and imposes no criminal liability on individuals who utilize cultural property for military purposes, nor does it define cultural objects, even to the extent of the Hague Convention. ${ }^{78}$ Its definitions are more in keeping with the 1907 Hague Regulations. ${ }^{79}$ Illegitimate looting or plunder are accountable. ${ }^{80}$ Yet despite the discrepancies between other international conventions and the Rome Statute, Article 21 of the statute states that the ICC must consider (1) its statutes, then 
(2) where appropriate, applicable IHL, and then (3) general principles of law derived from national systems if they are not inconsistent with international systems. This suggests that Article 8 should in fact be interpreted in light of the existing legal framework and that the two are complementary. However, this weakness in the Rome Statute means that the specific prosecution of cultural violations is largely a result of the will and interpretation of the prosecutor, so only a prosecution will determine how useful the ICC is. ${ }^{81}$

Deliberate attacks against cultural property during armed conflict, such as the destruction that occurred during the Balkan War in the 1990s, in Iraq in 2003, and in Mali in 2012, were deemed by the respective tribunals - the ICTY, the Iraqi High Criminal Court, and the ICC - to be potential or actual violations of the laws of warfare incurring individual criminal responsibility and thus, constituting "war crimes," setting a precedent for the prosecution of the destruction in Syria. ${ }^{82}$ The UN Human Rights Council has determined that many violations of IHL have occurred, including attacks against, and the pillaging and destruction of, cultural property, citing the Hague Convention and the Rome Statute and confirming some of the offences as war crimes. ${ }^{83}$ In addition, iconoclasm falls within the ICC's definition of war crime against cultural objects, and the specific unreasonable nature of iconoclasm may be taken into account as an aggravating factor when sentencing. Therefore, there would be grounds for prosecution by the ICC should they gain jurisdiction over the situation.

However, although Syria signed the Rome Statute in 2000 and should respect the provisions, it has not ratified it. Without this step, or unless Syria declares acceptance of the ICC's jurisdiction, the ICC will only have authority if the issue is referred to them by the UN Security Council. Given the divisions surrounding Syria in the UN Security Council, such unified action is unlikely. In 2013, 58 countries sent a letter to the UN Security Council requesting that the ICC begin an investigation into war crimes in Syria (referring to human rights abuses, not cultural war crimes). ${ }^{84}$ The referral was blocked by some Security Council permanent members, who stated that it might destabilize chances for a peaceful solution.

Even should a prosecution be made, there are limits on the ICC. Should a party fail to co-operate, the ICC can only refer the matter back to the Assembly of State Parties (the oversight and legislative body of the ICC) or to the UN Security Council. Furthermore, the ICC has no official police force: it is reliant on national authorities to apprehend suspects and transfer them to The Hague, requiring national co-operation. ${ }^{85}$

\section{State Prosecutions}

Under certain circumstances, a third option exists. Article 28 of the Hague Convention stipulates that all State parties must take all necessary steps to prosecute persons of whatever nationality who breach the convention, no matter where these violations took place (although whether such cases can actually be pursued in 
a particular country depends on its domestic laws). ${ }^{86}$ While it is theoretically feasible, whether this would actually take place is open to question. The willingness to investigate, prosecute, and punish crimes of this nature may be reinvigorated following the international outrage and condemnation of the deliberate destruction of historical sites occasioned by the Islamic State. If domestic prosecutions based on Article 28 do take place, however, they would be unprecedented.

\section{WAYS FORWARD}

There are difficulties in securing the prosecutions necessary to enforce the CPP framework. Issues include the focus and possible bias of nationally located courts; the lack of jurisdiction of the ICC and inadequacies of Article 8 of the Rome Statute; and the lack of international unity. Assuming a prosecution was made, there are difficulties in apprehending those guilty of violations. Given the many actors and groups involved in the Syrian conflict as well as the dangerous security situation, it would be difficult to identify those responsible for violations and even more difficult to apprehend and transport them. State co-operation would be essential, but there are large areas of the country that the State currently has little control over. Yet these difficulties have been overcome before.

In practice, cases must either be tried within Syria or referred to the ICC by Syrians or the United Nations (as a representative of States outside the affected territory). At present, the UN Security Council has failed to react in a unified, concrete way, and prosecutions are unlikely to come from Syria. Given this impasse, a new ad hoc tribunal, similar to the ICTY, has been suggested by the UN Commission of Inquiry that could focus exclusively on the Syrian situation. ${ }^{87}$ This will present its own problems in implementation-for example, defining a new legal framework, finding appropriate facilities, recruiting personnel, and ensuring state co-operation - and all from scratch, which will be both timely and costly. ${ }^{88}$

In 2013, the Chautauqua Blueprint was signed, which is a draft Statute for a Syrian Extraordinary Tribunal to Prosecute Atrocity Crimes. ${ }^{89}$ It was intended to sit in Damascus with predominantly Syrian judges, which has called its neutrality into question. The cultural crimes it would have jurisdiction over mirror those defined by the ICC, with all of its attendant problems. ${ }^{90}$ It is hoped that if an ad hoc tribunal were to be created, omissions such as this could be rectified.

\section{DA'ESH: A CASE STUDY}

The case of Syria is particularly complex due to the large number of non-state actors involved, many of whom have no official representation. It is therefore instructive to consider the most prominent of them-Da'esh. They have committed a number of prosecutable violations against cultural property within Syria, among many others, ${ }^{91}$ including destroying the Assyrian Lion statues in Raqqa with a bulldozer; the destruction of the Temples of Bel and Baalshamin, seven funerary 
towers, the triumphal arch, ${ }^{92}$ and the likely mining of the citadel and theatre at Palmyra. ${ }^{93}$ In addition, they have legalized the taxation of site looting and created a Ministry of Antiquities to officially control the looting of sites and the sale of objects, which has been confirmed by officials from the US State Department, Homeland Security, the Federal Bureau of Investigation, the US Department of Justice, and the United Nations at a conference held in September 2015 presenting newly declassified documents. ${ }^{94}$

It would be necessary to gather significantly more evidence of Syrian destruction than is currently available. The limited (confirmed) cultural destruction in Syria (for example, of the Assyrian Lion statues), while tragic, could hardly be considered a "grave breach" of IHL (although the extensive damage in Iraq could). The extent of the looting is hotly debated (particularly since the state of most of the sites was unknown before they occupied it), ${ }^{95}$ and many of the sites they have attacked were already occupied by a military force. The legality of the creation of the Ministry of Culture is unclear, but there are possible historical parallels. The Einsatstab Rosenberg was a Nazi educational research institute and museum containing more than 21,000 artworks stolen from countries across occupied Europe. The Nuremberg Charter vested the International Military Tribunal with jurisdiction over the war crime of plunder, and "in the context of belligerent occupation, the Tribunal held the accused Rosenberg [Chief of the Institute] 'responsible for a system of organised plunder of both public and private property through the invaded countries,"'96 for which he was found guilty. ${ }^{97}$

Da'esh has declared itself a state, but this state lacks formal recognition and has ratified no international treaties, raising the question of how to hold them accountable. Neither Syria nor Iraq, the countries where the new "state" is based, are members of the ICC and are unlikely to cede to ICC governance, even to enable the prosecution of Da'esh. Whether Da'esh can be referred to the ICC has been discussed, ${ }^{98}$ as this could constitute a "situation," but current arguments are undecided whether the group must be linked to territory. If not, it would open Da'esh up to prosecution for their actions globally, not just in Syria, but it also raises the question of the extent to which the state leaders are responsible for the actions of their members. If the ICC cannot prosecute, then the creation of an ad hoc tribunal, as was established for Rwanda, would allow the enforcement of IHL by the United Nations with non-member states. ${ }^{99}$

\section{A ROLE FOR THE INTERNATIONAL COMMUNITY?}

Any cases prosecuted will require evidence. There are already a number of organizations working on war crime documentation, including Human Rights Watch, the Syrian Observatory for Human Rights, and the Syria Justice and Accountability Center, but none have the specific remit of dealing with heritage. Activist groups, often utilizing social media, provide a large amount of information regarding the destruction of Syrian heritage, but many cannot be verified. Many are authentic 
and well intentioned, ${ }^{100}$ but some, such as Da'esh, are using the conflict as a source of propaganda to promote themselves and debase their enemies. In January 2014, the United Nations stopped updating the death toll as it could no longer verify its information, ${ }^{101}$ indicating the difficulties even for large organizations.

The DGAM has initiated a series of documentation and digitalization projects, providing some of the most reliable updates, but for obvious reasons as a state institution, they are remaining impartial and documenting only the damage, rather than the offences. Given the security situation and the decrease in resources, both physical and human, their documentation activities cannot be exhaustive. Local communities and unofficial bodies that are operating (for example, in Idlib) are also frequently unable to carry out proper documentation and protection work. It remains to be seen what role UNESCO will play, although throughout the conflict new projects have been announced to document and protect Syria's heritage. ${ }^{102}$ Evidence suggests that the damage is greater than supposed. Reports at sites such as Ebla note that looters are tunneling into them. ${ }^{103}$ Therefore, the extent cannot be known until it is possible to gain full access.

Many sites are occupied and re-occupied by competing parties as the conflict progresses. Damage reports not only indicate what happened, but when and potentially who was responsible. However, given the many caveats involved in modern methods to record damage, particularly involving social media, it remains to be seen whether they will be admissible in a court of law and how the caveats can be faced and dealt with. These problems are already making themselves felt in the field of human rights. ${ }^{104}$ Regardless, the international community in general must accept the responsibility of documenting the violations occurring and address the difficult issue of responsibility.

\section{CONCLUSIONS}

Through the overview of CPP legislation and with reference to the Syrian examples, this article has demonstrated that there is a significant level of protection for cultural property in both domestic and international laws governing archaeology and heritage. At a national level, and where possible at an international level, the Syrian DGAM has worked within the existing framework of domestic and international law, such as the World Heritage Convention, to try and protect its country's heritage. However, many other parties have failed to comply, and there are numerous violations - in particular, the utilization and targeting of heritage sites and monuments. Even the hands of the United Nations are tied and cannot offer Syria the support it needs. In May 2015, the United Nations unanimously adopted the resolution "saving the cultural heritage of Iraq," but it deliberately omitted Syria, apparently for political reasons. ${ }^{105}$ Given the lack of (or perhaps the impossibility of) the national or international enforcement of these frameworks during conflict, it must be concluded that they are inadequate for cultural property protection. Even after the conflict, enforcement will undoubtedly remain problematic, and it is 
doubtful to what extent, if any, prosecutions would act as a deterrent, particularly given that those involved in such war crimes are often involved in worse atrocities against the people whose heritage it belongs to, for which there does exist a body of prosecutions as precedent.

However, prosecutions are about more than determent. They serve justice. There remains a need to build up solid documentation to assist in potential prosecutions. This will be necessary for the future application of law in the country and to facilitate the preservation of heritage for future generations. Yet collecting documentation apportions responsibility for potential offences, which could be extremely dangerous for those involved. Documentation is therefore best conducted by an independent party, and it is unfortunate that it is the Syrian people who have the best access to such information. It may also be highly detrimental to peace building since parties responsible for the damage are likely to seek to avoid culpability, threatening the probably fragile atmosphere of co-operation. This in turn raises moral quandaries regarding priorities - is the price of justice worth the potential loss of peace? Others have argued, however, that such prosecutions can in fact enhance the peace process, as it removes those individuals who are most likely to be obstructive to the proceedings. ${ }^{106}$

While important, the available legal tools have not been effective in the protection of Syrian heritage, raising the question of whether force should be used. Ethical debates are only just beginning among the heritage community on whether this can be justified in this context, ${ }^{107}$ but at the time of writing, events may overtake them. While most feel that human lives must come first, making it difficult to prevent the use and abuse of cultural heritage, an armed brigade has formed in Syria to protect the holy shrine of Sayyeda Seinab, outside Damascus, ${ }^{108}$ and Turkey has cited the protection of an Islamic tomb when sending a military convoy into Syria. ${ }^{109}$ Now, as Da'esh control the strategically significant town of Tadmur, which contains the World Heritage site of Palmyra, the United States has reportedly agreed "that with the White House imprimatur, the UN Security Council will be strongly urged to etch a Chapter 7 'red-line' around Palmyra's archeological sites and defend them with whatever force and whatever cost required." 110 Most recently, UNESCO approved a strategy at their thirty-eighth General Conference for the Reinforcement of UNESCO's Action for the Protection of Culture and the Promotion of Cultural Pluralism in the Event of Armed Conflict, ${ }^{111}$ in which UNESCO agreed to encourage the inclusion of a cultural heritage component in UN peace-keeping forces' training and operations: "Ultimately, it is hoped that increased awareness of [sic] the military on international humanitarian cultural heritage law will lead to ... significant cultural heritage sites, which are clearly identified and protected from the conflict." This explicitly builds on the precedent that was created when the UN Security Council established a peacekeeping mission in Mali, the Multidimensional Integrated Stabilization Mission, to ensure security and political stability. Its mandate included assisting "the transitional authorities of Mali, as necessary 
and feasible, in protecting from attack the cultural and historical sites in Mali, in collaboration with UNESCO."112

A final point concerns the future of the Syrian people. If Syria is to survive this conflict, when reconstruction starts people will need their shared heritage in which all Syrians, no matter how different, can find common cause. Heritage authorities will face challenges such as the invention, implementation, and enforcement of a complete body of state and legal structures pertaining to the CPP. This will be particularly difficult given the emigration or loss of numerous heritage and legal staff and the attrition of the infrastructure. The criminalization of attacks against cultural property, as well as the efforts to protect the country's heritage, should not only be considered a Syrian issue but, rather, viewed from a global perspective as a concrete threat to modern, diverse societies. The targeting and destruction of cultural property and heritage in Syria can be viewed as attacks on the very essence of humanity. Efforts to safeguard cultural heritage in Syria, and to bring those involved in its destruction to justice, should therefore also be perceived as a humanitarian effort.

\section{ENDNOTES}

1. Viejo-Rose and Stig Sørenson 2015.

2. Isakhan 2013.

3. E.g., Chapman 1994.

4. Viejo-Rose 2013; Viejo-Rose and Stig Sørenson 2015.

5. Prosecutor v. Dario Kordic and Mario Cerkez (Trial Judgment) IT-95-14/2-T (26 February 2001).

6. Arimatsu and Choudhury 2014.

7. Human Rights Watch 2012.

8. In this context, State is distinct from state. A State (often referred to as a State party) is a country that is formally recognized internationally and which can sign international treaties and conventions.

9. Several other States have recently become involved in the Syrian conflict-for example, Russia, France, the United Kingdom - and in at least one case have been accused of damaging a World Heritage site. However, given the constraints of space, this article will focus on Syria and the non-State actors involved there, rather than the other State parties. See Ana Maria Luca and Myra Abdallah, "How Russia Bombed a UN Heritage Site in Syria," 10 May 2015, https://now.mmedia.me/ lb/en/reportsfeatures/565993-how-russia-bombed-a-un-heritage-site-in-syria (accessed 1 November 2015).

10. Lostal 2015.

11. Gerstenblith 2014.

12. While only 11 sites have been nominated, they make up 12 submitted nominations on the World Heritage Tentative List, as Dura Europos (8 June 1999) and Mari, Tell Hariri (8 June 1999) were submitted separately, but have a twelfth nomination as a joint submission (Mari and EuroposDura sites of the Euphrates Valley (23 June 2011).

13. Lostal 2015.

14. E.g., Amnesty International and American Association for the Advancement of Science 2013; World Heritage Committee 2013, 2014; Abdulkarim 2014; Cunliffe et al. 2014; Wolfinbarger et al. 2014a, 2014b.

15. Kila 2012. 
16. E.g., Cunliffe 2012; Association for the Protection of Syrian Archaeology, http://www. apsa2011.com (accessed 30 May 2014).

17. Cunliffe 2014.

18. International Council on Monuments and Sites 2011.

19. Boldrick, Brubaker, and Clay 2013.

20. Kila 2013.

21. Cunliffe et al. 2014.

22. Howard, Prohov, and Elliott 2015. Given the constraints of this article, only brief attention is given to Da'esh as they are largely treated as a non-State actor.

23. Convention for the Protection of Cultural Property in the Event of Armed Conflict, 14 May 1954, 249 UNTS 240 (Hague Convention). The term cultural "property" is now widely considered to be deficient. See Prott and O'Keefe (1992) for its failure to incorporate diverse forms of heritage. However, "cultural heritage" has yet to receive widespread implementation or to be legally tested.

24. International Committee of the Red Cross, "Customary International Humanitarian Law," 29 October 2010, http://www.icrc.org/eng/war-and-law/treaties-customary-law/customary-law/ overview-customary-law.htm (accessed 13 May 2014).

25. Universal Declaration of Human Rights, 12 October 1948, UN Doc A/810 at 71 (1948).

26. International Covenant on Economic, Social and Cultural Rights, 16 December 1966, 993 UNTS 3.

27. O'Keefe 2014. UN Human Rights Council, Resolution 6/1, 27 September 2007.

28. Cunliffe et al. 2014.

29. Geneva Conventions of 12 August 1949, 1125 UNTS 3.

30. Protocol Additional to the Geneva Conventions of 12 August 1949, and Relating to the Protection of Victims of Non-International Armed Conflicts, 8 June 1977, 1125 UNTS 609.

31. Hague Convention IV on Respecting the Laws and Customs of War on Land and its Annex: Regulation concerning the Laws and Customs of War on Land 1907, 187 CTS 227.

32. Convention on the Means of Prohibiting and Preventing the Illicit Import, Export and Transfer of Ownership of Cultural Property, 14 November 1970, 823 UNTS 231. Antiquities Law, 26 October 1963, Decree no. 222.

33. Convention on Stolen or Illegally Exported Cultural Objects, 24 June 1995, 2421 UNTS 457. There is a range of international laws and examples dealing with prosecutions for illegally removed objects seized outside the country of origin, but these are outside the scope of this article.

34. Prott and O'Keefe 1992.

35. For a full discussion, see Prott and O'Keefe 1984; Toman 1996; O'Keefe 2006; Kila 2012; Frulli 2011; Ehlert 2014.

36. Gerstenblith 2014.

37. Vienna Convention on the Law of Treaties, 23 May 1969, 1155 UNTS 331.

38. Henckaerts 2005.

39. Ibid., 178 .

40. Gerstenblith 2010, 2014; Henckaerts 2005.

41. C.J. Chivers, "Grave Robbers and War Steal Syria’s History," New York Times, 6 April 2013, http://www.nytimes.com/2013/04/07/world/middleeast/syrian-war-devastates-ancient-sites.html?_ $\mathrm{r}=0 \& a d x n n l=1 \& a d x n n l x=1381999297-u Z k V l 2 q R T 6 D 6 k i J 7 d G E r w A$ (accessed 17/10/2013). See also Patrick Cockburn, "The Destruction of the Idols: Syria's Patrimony at Risk from Extremists," The Independent, 11 February 2014, http://www.independent.co.uk/news/science/archaeology/news/thedestruction-of-the-idols-syrias-patrimony-at-risk-from-extremists-9122275.html (accessed 20 May 2014).

42. Casana and Panahipour 2014.

43. Gerstenblith 2010, 9.

44. Bogliolo 2012.

45. Lostal 2012. The definition of military objective is provided in Article 52(2) of Additional Protocol I and considered to be part of customary international law: “[M]ilitary objectives are limited 
to those objects which by their nature, location, purpose or use make an effective contribution to military action and whose total or partial destruction, capture or neutralization, in the circumstances ruling at the time, offers a definite military advantage."

46. O'Keefe 2008, 2014.

47. See Lostal 2012, 470.

48. For examples of discussions and court rulings, see O'Keefe 2006, 130, 131.

49. For example, in Libya, the North Atlantic Treaty Organization selected more focused ordnance when attacking a military target to protect a site. See Kila 2012.

50. Kila 2012.

51. Abdulkarim 2014.

52. Cunliffe et al. 2014.

53. E.g., "Appel à la préservation des musées syriens adressé aux institutions internationales et à la communauté internationale," Le patrimoine Syrien archéologique en danger, 30 April 2012, https://www.facebook.com/notes/le-patrimoine-arch\%C3\%A9ologique-syrien-en-danger\%D8\%A7\%D9\%84\%D8\%A2\%D8\%AB\%D8\%A7\%D8\%B1-\%D8\%A7\%D9\%84\%D8\%B3\% D9\%88\%D8\%B1\%D9\%8A\%D8\%A9-\%D9\%81\%D9\%8A-\%D8\%AE\%D8\%B7\%D8\%B1/appel\%C3\%A0-la-pr\%C3\%A9servation-des-mus\%C3\%A9es-syriens-adress\%C3\%A9-aux-institutionsinternationa/311246265610371 (accessed 30 May 2014).

54. Gerstenblith 2010, 9.

55. Ali 2013.

56. Henckaerts 2005, Annex.

57. Ibid.

58. For a full commentary on this treaty, see Prott and O'Keefe 1988; O'Keefe and Patrick 1997; O'Keefe 2007; UNESCO 2011.

59. Brodie 2008; compare Sam Hardy, "Syria/Lebanon: Syrian-Lebanese Antiquities-for-Arms Trade," Conflict Antiquities Blog, 12 May 2013, http://conflictantiquities.wordpress.com/2013/05/12/ syria-conflict-funding-lebanon-illicit-antiquities-trade/ (accessed 01 May 2014).

60. Workshop on "Countering the Destruction of and Trafficking in Cultural Property: From Lessons Learned to Implementation," 3 June 2015, United Nations Headquarters, New York.

61. Cunliffe 2014.

62. Aryn Baker and Majdal Anjar, "Syria's Looted Past: How Ancient Artifacts Are Being Traded for Guns," Time World, 12 September 2012, http://world.time.com/2012/09/12/syrias-looted-pasthow-ancient-artifacts-are-being-traded-for-guns/ (accessed 12 September 2012); see also Hardy, "Syria/Lebanon."

63. E.g., Association for the Protection of Syrian Archaeology (APSA), "Alep Henano: Destruction la coupole du Meqam Cheikh Yebreq," YouTube, https://www.youtube.com/watch?v=eEBE3Issjuw (accessed 1 July 2013); Robert Fisk, "Syria's Ancient Treasures Pulverised," The Independent, 5 August 2012, http://www.independent.co.uk/opinion/commentators/fisk/robert-fisk-syrias-ancient-treasurespulverised-8007768.html (accessed 6 August 2012); "Damage at the Tomb of Shaykh Abdallah Sirajuddin," Free Halab Blog, 26 November 2012, http://freehalab.wordpress.com/2012/11/26/damageat-the-tomb-of-shaykh-abdallah-sirajuddin/; "Shaykh al-Yaqoubi Condemns the Bombing of Shrines in Aleppo," Free Halab Blog, 24 November 2012, http://freehalab.wordpress.com/2012/11/24/shaykhal-yaqoubi-condemns-the-bombing-of-shrines-in-aleppo/ (both accessed 13 May 2014); Human Rights Watch 2012.

64. E.g., Human Rights Watch 2012; Mediawerkgroep Syrie, "Desecrated Churches in Homs," 17 June 2012, http://mediawerkgroepsyrie.wordpress.com/2012/06/17/desacrated-churches-in-homs-pdf/ (accessed 1 December 2012).

65. By mid-2013. The date of a report by Syrian Network for Human Rights, Targeting Mosques, 11 June 2013, http://sn4hr.org/public_html/wp-content/pdf/english/Targeting\%20Mosques\%20 by\%20Syrian.pdf (accessed 30 May 2015).

66. Convention Concerning the Protection of the World Cultural and Natural Heritage, 23 November 1972, 1037 UNTS 151 (World Heritage Convention). 
67. Convention for the Safeguarding of Intangible Cultural Heritage, 17 October 2003, 2368 UNTS 3.

68. Convention on the Protection and the Promotion of the Diversity of Cultural Expressions, 20 October 2005, 2440 UNTS 311. Due to the complexities of underwater ownership and the fact that conflict rarely affects underwater sites, the UNESCO Convention on the Protection of the Underwater Cultural Heritage, 2 November 2001, 41 ILM 40 (2002) will not be discussed here.

69. For a detailed discussion of the extent to which the definition of heritage in the World Heritage Convention is legally binding in armed confllicts, and the legal implications for the protection of World Heritage sites. See Lostal 2015.

70. Declaration Concerning the Intentional Destruction of Cultural Heritage, Paris, 17 October 2003, http://portal.unesco.org/en/ev.php-URL_ID=17718\&URL_DO=DO_TOPIC\&URL_SECTION=201. html (accessed 10 May 2014).

71. Directorate General of Antiquities and Museums (DGAM), "Completing New Draft Law on Protection of Syria's Archaeological Heritage," DGAM, http://www.DGAM.gov.sy/index. php?d=314\&id=1114 (accessed 13 May 2014). Perhaps in support of this, during 2014, legal experts, officials from the DGAM, and other official Syrian bodies collaborated with UNESCO in order to shed light on the expected benefits of the application of the Second Protocol of the Hague Convention in the Syrian case.

72. Suleiman Al-Khalidi, "Syrian Violence Threatens Ancient Treasures," Reuters, 20 February 2013, http://www.reuters.com/article/2013/02/20/uk-syria-crisis-antiquities-idUSLNE91J01C20130220 (accessed 21 February 2013).

73. World Heritage Committee 2013, 115.

74. Kila 2012.

75. For a full discussion of the prosecution of cultural crimes, see Carcano 2013; Ehlert 2014. For brevity, this article will not discuss the sentencing of cultural crimes. It is extremely difficult to establish the value of heritage. (For some examples of methods used, see Darvill, Saunders, and Startin 1987; Darvill and Fulton 1998; Isakhan 2014). In addition, it is likely that, as concepts of cultural heritage and cultural property are refined in the heritage and legal spheres, value discussions will change.

76. Human Rights Council 2013, 124.

77. Rome Statute on the International Criminal Court, 17 July 1998, 2187 UNTS 90.

78. Gottlieb 2004, 857.

79. Frulli 2011.

80. O’Keefe 2006, 348.

81. Carcano 2013.

82. See Art. 3(d) of the Statute of the International Tribunal for the Prosecution of Persons Responsible for Serious Violations of International Humanitarian Law Committed in the Territory of the Former Yugoslavia since 1991, 25 May 1993, 32 ILM 1159 (1993); Arts. 13(b)(14) and 13(b)(17) of the Statute of the Iraqi Special Tribunal, 10 December 2003.

83. Human Rights Council 2013, 22.

84. Thomas Gürber, Letter to the President of the UN Security Council, January 2013, http://www. news.admin.ch/NSBSubscriber/message/attachments/29293.pdf (accessed 30 May 2015).

85. For other problems regarding the enforcement of cultural property protection, see Lenzerini 2013.

86. Human Rights Watch, "Syria and the International Criminal Court: Questions and Answers," September 2013, http://www.hrw.org/sites/default/files/related_material/Q\&A_Syria_ICC_Sept2013_ en_0.pdf (accessed 30 May 2015).

87. Human Rights Council, "Commission of Inquiry on the Syrian Arab Republic: Press Conference," http://webtv.un.org/media/press-conferences/watch/commission-of-inquiry-on-the-syrian-arabrepublic-press-conference-geneva-17-march-2015/4116607036001\#full-text (accessed 30 May 2015).

88. Human Rights Council 2013, 125.

89. Chautauqua Institution, "The Chautauqua Blueprint for a Statute for a Syrian Extraordinary Tribunal to Prosecute Atrocity Crimes," September 2013, http://insct.syr.edu/wp-content/ uploads/2013/09/Chautauqua-Blueprint1.pdf (accessed 30 May 2015). 
90. For a more detailed discussion, see Lostal 2015.

91. In fact, there have been at least 50 incidents of varying severity attributed to Da'esh in Syria alone. See "ISIS Destroys Mausoleums in Syria's Palmyra," Al-Arabiya News, 23 June 2015, http:// english.alarabiya.net/en/News/middle-east/2015/06/23/ISIS-destroys-Islamic-mausoleums-in-Syrias-Palmyra-.html (accessed 10 November 2015).

92. These events are confirmed in the regular reports published online by the ASOR Cultural Heritage Initiative, http://www.asor-syrianheritage.org/reports/ (accessed 10 November 2015).

93. Reported in The Independent on 21 June 2015 and again in Sputnik News on 6 October 2015 (where the theatre is incorrectly identified as the amphitheater). Neither incident is verified; it may even be the same report. See Alexander Sehmer, "Isis Fighters 'Plant Mines' around Ancient Palmyra Site,” The Independent, 21 June 2015, http://www.independent.co.uk/news/world/middle-east/isisfighters-plant-mines-around-ancient-palmyra-site-10335128.html (accessed 10 November 2015); and Sputnik News, "ISIL Rigs Palmyra's Ancient Roman Amphitheater with Explosives," Sputnik News, 06 October 2015, http://sputniknews.com/middleeast/20151006/1028118213/palmyra-syriaisil-theater.html - ixzz3nuKaUFFX (accessed 10 November 2015).

94. The event was Conflict Antiquities: Forging a Public/Private Response to Save Iraq and Syria's Endangered Cultural Heritage, which was held 29 September 2015 and organized by the Department of State and the Metropolitan Museum of Art. In addition to podcasts of the event, some slides and documents have been released, and several blogs have summarized the event. The UK Blue Shield website has collated all the links into one place for those wishing further information, http:// ukblueshield.org.uk/events/previous-events/conflict-antiquities-forging-a-publicprivate-responseto-save-iraq-and-syrias-endangered-cultural-heritage/ (accessed 10 November 2015).

95. See the many articles debunking Da'esh myths by Sam Hardy in his Conflict Antiquities Blog, https://conflictantiquities.wordpress.com/ (accessed 10 November 2015).

96. O’Keefe 2010, 337.

97. Nowlan 1993.

98. Alexander Skander Galand, "The Situation Concerning the Islamic State: Carte Blanche for the ICC if the Security Council Refers?” EJIL: Talk! Blog, 27 May 2015, http://www.ejiltalk.org/the-situationconcerning-isis-carte-blanche-for-the-icc-if-the-security-council-refers/ (accessed 30 May 2015).

99. Anthony Moreland, "In the Absence of Sovereignty, How Will ISIS Be Held Accountable for Their Crimes?” National Security and Armed Conflict Law Review, 10 February 2015, http://nsac.law. miami.edu/absence-sovereignty-isis-held-accountable/ (accessed 30 May 2015).

100. Perini and Cunliffe 2014a, 2014b, 2015.

101. Kashmira Gander, "UN to Stop Updating Death Toll in Syria Conflict," The Guardian, 07 January 2014, http://www.independent.co.uk/news/world/middle-east/un-to-stop-updating-death-toll-in-syriaconflict-9045096.html?origin=internalSearch (accessed 13 May 2014).

102. UN News Centre, “With Syria’s Culture Near 'Point of No Return': UN Agency to Create Safeguard Observatory," UN Website, http://www.un.org/apps/news/story.asp?NewsID=47911 - .U4jFOvldWoP (accessed 30 May 2014).

103. Abdulkarim 2014; see also C.J. Chivers, "Grave Robbers and War Steal Syria’s History,” New York Times, 6 April 2013, http://www.nytimes.com/2013/04/07/world/middleeast/syrian-war-devastatesancient-sites.html?_r=0\&adxnnl=1\&adxnnlx=1381999297-uZkVl2qRT6D6kiJ7dGErwA (accessed 17 October 2013).

104. Centre for Human Rights and Global Justice, "2012-14 Initiative on Human Rights Fact-Finding, Methods and Evidence," NYU School of Law Webpage, http://chrgj.org/project/2012-14-theme-humanrights-fact-finding-methods-and-evidence/ (accessed 30 May 2015).

105. Cara Anna, "Syria: Europeans Block It from UN Culture Protection Measure," Associated Press, 28 May 2015, http://news.yahoo.com/syria-europeans-block-un-culture-protection-measure-201902142. html (accessed 15 June 2015).

106. Human Rights Watch, "Syria and the International Criminal Court: Questions and Answers." 107. Sam Hardy, "Should Cultural Monuments Become an Active Issue of the Human Rights Agenda?” Conflict Antiquities Blog, 12 May 2013, http://conflictantiquities.wordpress.com/2014/04/12/ 
amnesty-international-political-violence-cultural-property-community-persecution/ (accessed 01 May 2014).

108. M. Karouney, "Shi' ite Fighters Rally to Defend Damascus Shrine," Reuters, 03 March 2013, http://www.reuters.com/article/2013/03/03/us-syria-crisis-shiites-idUSBRE92202X20130303?feed Type=RSS\&feedName=worldNews\&utm_source=feedburner\&utm_medium=feed\&utm_campaign= Feed\%3A+Reuters\%2FworldNews+\%28Reuters+World+News\%29 (accessed 14 April 2014).

109. C. Labrousse, "Turkey Army Convoy Entered Northern Syria to Protect Tomb," Arab Chronicle, 24 April 2014, http://the-arab-chronicle.com/turkey-army-convoy-entered-in-northernsyria/ (accessed 25 April 2014).

110. Franklin Lamb, “The Fall of Palmyra," Counterpunch, 21 May 2015, http://www.counterpunch. org/2015/05/21/the-fall-of-pamyra/ (accessed 30 May 2015).

111. UNESCO 2015, 7, point 35.

112. Doc. S/RES/2100 (2013), para. 16(f); Doc. S/RES/2164 (2014), para. 14(b).

\section{BIBLIOGRAPHY}

Abdulkarim, Maamoun. 2014. Annual Report 2013. Damascus: Directorate General of Antiquities and Museums.

Ali, Cheikhmous. 2013. "Syrian Heritage under Threat." Journal of Eastern Mediterranean Archaeology and Heritage Studies 1, no. 4: 351-66.

Amnesty International and American Association for the Advancement of Science. 2013. Conflict in Aleppo, Syria: A Retrospective Analysis. Geospatial Technologies and Human Rights Project. London and Washington, DC: Amnesty International and American Association for the Advancement of Science.

Arimatsu, Louise, and Mohuba Choudhury. 2014. The Legal Classification of the Armed Conflicts in Syria, Yemen and Libya. International Law Series. London: Chatham House.

Bogliolo, Luis Paulo. 2012. "Rethinking Military Necessity in the Law of Armed Conflict." Unpublished PhD diss., University of Brasilia and London School of Economics and Political Science, http://papers. ssrn.com/sol3/papers.cfm?abstract_id=2201129.

Boldrick, Stacy, Leslie Brubaker, and Richard Clay, eds. 2013. Striking Images, Iconoclasms Past and Present. Farnham, UK: Ashgate Publishing.

Brodie, Neil. 2008. "The Market Background to the April 2003 Plunder of the Iraq National Museum." In The Destruction of Cultural Heritage in Iraq, edited by P. G. Stone, and Joanne Farchakh-Bajjaly, 41-54. Woodbridge, UK: Boydell Press.

Carcano, Andrea. 2013. "The Criminalization and Prosecution of Attacks against Cultural Property." In War Crimes and the Conduct of Hostilities: Challenges to Adjudication and Investigation, edited by F. Pocar, M. Pedrazzi, and M. Frulli, 78-97. Cheltenham, UK: Edward Elgar.

Casana, Jesse, and Mitra Panahipour. 2014. "Satellite-Based Monitoring of Looting and Damage to Archaeological Sites in Syria." Journal of Eastern Mediterranean Archaeology and Heritage Studies 2, no. 2: 128-51.

Chapman, John. 1994. "Notes: Destruction of a Common Heritage: The Archaeology of War in Croatia, Bosnia and Hercegovinia." Antiquity 68, no. 1: 120-26.

Cunliffe, Emma. 2012. Damage to the Soul: Syria's Cultural Heritage in Conflict. Palo Alto, CA: Global Heritage Fund. 
2014. "Archaeological Site Damage in the Cycle of War and Peace: A Syrian Case Study." Journal of Eastern Mediterranean Archaeology and Heritage Studies 3, no. 2: 229-47.

Cunliffe, Emma, Wendi Pederson, Manuel Fiol, Traci Jellison, Caryn Saslow, Einar Bjørgo, and Giovanni Boccardi. 2014. Satellite-based Damage Assessment to Cultural Heritage Sites in Syria. Geneva: UN Institute for Training and Research.

Darvill, Timothy, and Andrew K. Fulton, eds. 1998. MARS: The Monuments at Risk Survey of England, 1995. Bournemouth, UK: School of Conservation Sciences, Bournemouth University.

Darvill, Timothy, Andrew Saunders, and Bill Startin. 1987. "A Question of National Importance: Approaches to the Evaluation of Ancient Monuments for the Monuments Protection Programme in England." Antiquity 61, no. 3: 393-408.

Ehlert, Caroline. 2014. Prosecuting the Destruction of Cultural Property in International Criminal Law: With a Case Study on the Khmer Rouge's Destruction of Cambodia's Heritage. Leiden: Brill.

Frulli, Micaela. 2011. "The Criminalization of Offenes against Cultural Heritage in Times of Armed Conflict: The Quest for Consistency.” European Journal of International Law 22, no. 1: 203-17.

Gerstenblith, Patty. 2010. "The Obligations Contained in International Treaties of Armed Forces to Protect Cultural Heritage in Times of Armed Conflict." In Archaeology, Cultural Property, and the Military, edited by L. W. Rush, 4-14. Woodbridge, UK: Boydell Press.

- 2014. "Beyond the 1954 Hague Convention." In Cultural Awareness in the Military: Developments and Implications for Future Humanitarian Cooperation, edited by R. Albro, and B. Ivey, 83-98. New York: Palgrave Macmillan.

Gottlieb, Yaron. 2004. "Criminalizing Destruction of Cultural Property: A Proposal for Defining New Crimes under the Rome Statute of the ICC.” Penn State International Law Review 23: 857.

Henckaerts, Jean-Marie. 2005. "Study on Customary International Humanitarian Law: A Contribution to the Understanding and Respect for the Rule of Law in Armed Conflict." International Review of the Red Cross 87, no. 857: 175-212.

Howard, Russell, Jonathan Prohov, and Marc Elliott. 2015. "Digging in and Trafficking Out: How the Destruction of Cultural Heritage Funds Terrorism." CTC Sentinel, Combating Terrorism Center, 27 February 2015, https://www.ctc.usma.edu/posts/digging-in-and-trafficking-out-how-thedestruction-of-cultural-heritage-funds-terrorism.

Human Rights Council. 2013. Report of the Independent International Commission of Inquiry on the Syrian Arab Republic. Washington, DC: UN General Assembly, Human Rights Council.

Human Rights Watch. 2012. "They Burned My Heart." War Crimes in Northern Idlib during Peace Plan Negotiations. Washington, DC: Human Rights Watch.

International Council on Monuments and Sites. 2011. Ancient Villages of Northern Syria (Syrian Arab Republic). No 1348. Advisory Body Evaluation. 10 March. Paris: UNESCO.

Isakhan, Benjamin. 2013. "Heritage Destruction and Spikes in Violence: The Case of Iraq." In Cultural Heritage in the Crosshairs. Protecting Cultural Property During Conflict, edited by J. D. Kila, and J. A. Zeidler, 219-48. Leiden: Brill.

2014. "Creating the Iraq Cultural Property Destruction Database: Calculating a Heritage Destruction Index." International Journal of Heritage Studies 1, no. 1: 1-21. 
Kila, Joris D. 2012. Heritage under Siege: Military Implementation of Cultural Property Protection Following the 1954 Hague Convention, Heritage and Identity. Leiden: Brill.

- 2013. "Inactive, Reactive, or Pro-active?" Journal of Eastern Mediterranean Archaeology and Heritage Studies 1, no. 4: 319-42.

Lenzerini, Federico. 2013. "The Role of International and Mixed Criminal Courts in the Enforcement of International Norms Concerning the Protection of Cultural Heritage." In Enforcing International Cultural Heritage Law, edited by F. Francioni, and J. Gordley, 40-64. Oxford: Oxford University Press.

Lostal, Marina. 2012. “The Meaning and Protection of 'Cultural Objects and Places of Worship' under the 1977 Additional Protocols." Netherlands International Law Review 59, no. 3: 455-72.

2015. "Syria’s World Cultural Heritage and Individual Criminal Responsibility." International Review of Law 3: 1-17.

Nowlan, Jacqueline. 1993. "Cultural Property and the Nuremberg War Crimes Trial." Humanitaeres Voelkerrecht 6, no. 4: 221-23.

O'Keefe, Patrick J. 2007. Commentary on the UNESCO 1970 Convention on the Means of Prohibiting and Preventing the Illicit Import, Export and Transfer of Ownership of Cultural Property. Powys, UK: Institute of Art and Law.

O'Keefe, Roger. 2006. The Protection of Cultural Property in Armed Conflict. Cambridge: Cambridge University Press.

- 2008. "Protection of Cultural Property." In The Handbook of International Humanitarian Law, edited by D. Fleck, 433-74. Oxford: Oxford University Press.

- 2010. "Protection of Cultural Property under International Criminal Law." Melborne Journal of International Law 11: 339-92.

2014. "Protection of Cultural Property." In Oxford Handbook of International Law in Armed Conflict, edited by A. Clapham, and P. Gaeta, 492-520. Oxford: Oxford University Press.

O’Keefe, Roger, and J. Patrick. 1997. Trade in Antiquities. Paris: UNESCO.

Perini, Silvia, and Emma Cunliffe. 2014a. Towards a Protection of the Syrian Cultural Heritage: A Summary of the International Responses (April 2014 -September 2014), Vol. 2. Girona, Spail: Heritage for Peace.

- 2014b. Towards a Protection of the Syrian Cultural Heritage: A Summary of the International Responses (March 2011-March 2014), Vol. 1. Girona, Spain: Heritage for Peace.

2015. Towards a Protection of the Syrian Cultural Heritage: A Summary of the National and International Responses (September 2014 —September 2015), Vol. 3. Girona, Spain: Heritage for Peace.

Prott, Lyndel V., and Patrick J. O'Keefe. 1984. Law and the Cultural Heritage. Abingdon, UK: Professional Books.

1988. Handbook of National Regulations Concerning the Export of Cultural Property. Paris: UN Educational, Scientific and Cultural Organization (UNESCO).

1992. “'Cultural Heritage' or 'Cultural Property.'” International Journal of Cultural Property 1, no. 2: 307-20. 
Toman, Jirí. 1996. The Protection of Cultural Property in the Event of Armed Conflict: Commentary on the Convention for the Protection of Cultural Property in the Event of Armed Conflict and Its Protocol, Signed on 14 May, 1954 in The Hague, and on Other Instruments of International Law Concerning Such Protection. Paris: UNESCO.

UNESCO. 2011. The Fight against the Illicit Trafficking of Cultural Objects. 1970 Convention: Past and Future: Information Kit. Paris: UNESCO.

2015. Item 4.11 of the Provisional Agenda 38 C/49: Reinforcement of UNESCO's Action for the Protection of Culture and the Promotion of Cultural Pluralism in the Event of Armed Conflict. ThirtySeventh Session. Paris: UNESCO.

Viejo-Rose, Dacia. 2013. "Reconstructing Heritage in the Aftermath of Civil War: Re-Visioning the Nation and the Implications of International Involvement." Journal of Intervention and Statebuilding: Special Issue on Cultural Interventions 7, no. 2: 125-48.

Viejo-Rose, Dacia, and Marie Louise Stig Sørenson. 2015. "Cultural Heritage and Armed Conflict: New Questions for an Old Relationship." In The Palgrave Handbook of Contemporary Heritage Research, edited by E. Waterton, and S. Watson, 281-96. Basingstoke, UK: Palgrave Macmillon.

Wolfinbarger, Susan, Jonathan Drake, Eric Ashcroft, and Kathryn Hanson. 2014a. Ancient History, modern destruction: Assessing the current status of Syria's World Heritage Sites Using High Resolution Satellite Imagery. Washington, DC: American Association for the Advancement of Science and Smithsonian Institution.

- 2014b. Ancient History, Modern Destruction: Assessing the Status of Syria's Tentative World Heritage Sites Using High-Resolution Satellite Imagery, Part 1. Washington, DC: American Association for the Advancement of Science and Smithsonian Institution.

World Heritage Committee. 2013. Item 7B of the Provisional Agenda: State of Conservation of World Heritage Properties Inscribed on the World Heritage List. Convention Concerning the Protection of the World Cultural and Natural Heritage. Thirty-Seventh Session. Doc. WHC-13/37.COM/7B.ADD. Paris: UNESCO.

-2014. Item 7A of the Provisional Agenda: State of Conservation of the Properties Inscribed on the List of World Heritage in Danger. Convention Concerning the Protection of the World Cultural and Natural Heritage. Thirty-eighth Session. Doc. WHC-14/38.COM/7A.Add. Paris: UNESCO. 